\title{
OPTICAL FREQUENCY TRANSDUCER BASED ON DUAL-GATE MOSFET WITH AN ACTIVE INDUCTIVE ELEMENT
}

\author{
Alexandr V. Osadchuk, Vladimir S. Osadchuk, Olena O. Seletska, Lyudmila V. Krylik \\ Vinnitsa National Technical University, Vinnitsa, Ukraine
}

Background. A perspective trend in the development of optical radiation transducers is using of dependencies of reactive properties of semiconductor transistor structures with negative resistance on optical radiation effect and creation of frequency optical radiation transducers on the basis of these properties. Application of optical-frequency transformation enhances noise stability, accuracy and enables to expand a measuring range, to obtain outputs higher than amplitude ones and to improve metrological performances of the transducers. Using frequency as an informative parameter allows excluding the analog-to-digital transducers during information processing, and reducing the cost of monitoring and control systems. The principle of "optical power $\square$ frequency" transformation can be implemented using semiconductor structure containing self-sustained oscillator and photoresistor as a photosensitive element. Active inductance resolves the problem of low quality factor inherent in the passive inductor. Furthermore, it overcomes compatibility issue of passive inductor's size with the integrated circuit's sizes and allows completely making transducer as an integrated circuit. So, it is necessary to construct a mathematical model of the optical frequency transducer to analyze its properties and to obtain the dependencies of active and reactive components of the impedance of the semiconductor structure, the equation of sensitivity and the transfer function.

Objective. The aim of the paper is to determine the transfer function and equation of sensitivity for optical transducer with an active inductive element by solving Kirchhoff's system of equations composed for equivalent circuit of the transducer.

Methods. The determination of the transistor structure impedance was made by solving the Kirchhoff's system of equations, composed for equivalent circuit of frequency optical transducer. The characteristics describing dependencies of reactive and active components of the oscillator's impedance on optical power were obtained by computer simulation using the MATLAB numerical computing environment.

Results. The mathematical model for description of the properties of frequency optical transducer with an active inductive element was developed. The transform function and relative sensitivity analytical equations were estimated to describe the action of transducer. The values of relative sensitivity are equal to $2-11.5 \mathrm{kHz} / \mu \mathrm{Wt} / \mathrm{cm}^{2}$. Accuracy of developed mathematical model is $\pm 5 \%$.

Conclusions. The optical transducer with an active inductive element has a high sensitivity in the range of low values of optical power. It makes possible to measure even low optical signals. Proposed model describes the dependence of the impedance of the transistor structure - which is basic for the transducer - on power of optical radiation.

Keywords: optical transducers; frequency transducers; negative resistance; photoresistor.

\section{Introduction}

At present, optical transducers are widely used as a component of automated control systems for positioning, calculating, sorting elements and performing other tasks for any processing line. Application of optical transducers allows controlling the distance, size, level, color and degree of transparency. Optical non-contact transducers are widely used in industry due to their high reliability, resistance to external factors, long distances operation [1-3].

A perspective trend in the development of optical radiation transducers is use of dependencies of reactive properties of semiconductor transistor structures with negative resistance $[4,5]$ on optical radiation effect and creation frequency optical radiation transducers on the basis of these properties.

An application of optical-frequency transformation enhances noise stability, accuracy and enables to expand a measuring range, obtain outputs higher than amplitude ones and to improve metrological performances of the transducers. [6,7].

Also, the employing of such devices makes possible "smart" transducers as a result of the combination data processing circuits and the primary sensor on a single chip. Using frequency as an informative parameter allows excluding the analog-to-digital transducers during information processing, and reducing the cost of monitoring and control systems. [8].

The principle of "optical power - frequency" transformation can be implemented using semiconductor 
structure containing self-sustained oscillator and photoresistor as a photosensitive element. The selfsustained oscillator is a circuit consisting of the dual gate MOS-transistors and a bipolar transistor. Bipolar transistor with a phase-shift RC-circuit forms an active inductive element in this structure. Active inductance resolves the problem of low quality factor inherent in the passive inductor. Furthermore, it overcomes compatibility issue of passive inductor's size and the sizes of integrated circuit and allows making transducer completely as an integrated circuit.

It is necessary to construct a mathematical model of the optical frequency transducer to analyze its properties and to obtain the dependencies of active and reactive components of the impedance of the semiconductor structure, the equation of sensitivity and the transfer function.

The aim of the study is to determine the transfer function and equation of sensitivity for optical transducer with an active inductive element by solving Kirchhoff's equations composed for equivalent circuit of the transducer [9].

\section{Theoretical and Experimental Research}

The circuit of frequency optical transducer based on field-effect transistors with active inductive element and photoresistor as a sensing element is shown in Fig. 1.

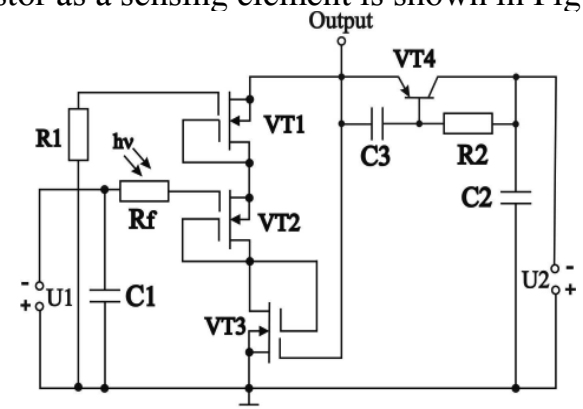

Fig. 1. Circuit of frequency optical transducer based on MOSFET optical transducer with an active inductive element

There is an impedance, which active component has a negative value, and reactive component - capacitive character on electrodes between drain and source of MOSFET transistors as a result of action of a positive feedback. The circuit in Fig. 1 contains oscillator of electric oscillations formed by the capacitive component of the impedance on electrode drain-source of VT1 and VT3 MOSFET transistors and inductive component of the impedance on electrodes emitter-collector of bipolar transistor VT4.

It needs to build passive inductor using film technology to produce optical transducer as an integrated circuit. However, this inductor has a low Q-factor and its dimensions on the frequencies of $10^{6} \mathrm{~Hz}$ are not compatible with the dimensions of transducer semiconductor chip [11]. Thereby, application of inductive character of the impedance bipolar transistor VT4 with a phase shift RC-circuit as an oscillator circuit inductor was proposed to solve this problem. The shift $\mathrm{RC}$-circuit is based on the resistor R3 and capacitor C3.

The equivalent circuit for alternating current has been made to determine an impedance of the oscillator (Fig. 2).

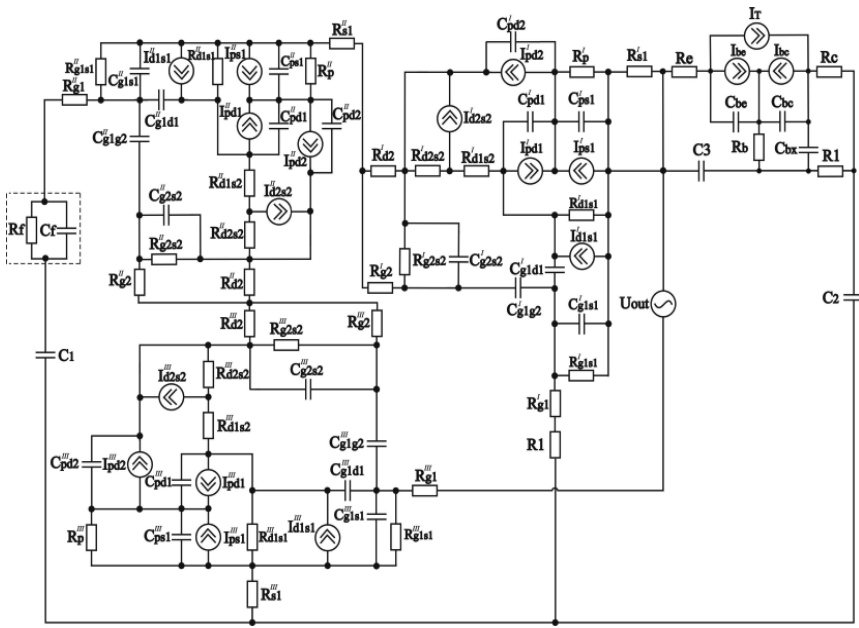

Fig. 2. Equivalent AC circuit of optical transducer with an active inductive element

The equivalent circuit of the frequency optical transducer for alternating current, transformed into more convenient for calculations, is presented in Fig. 3.

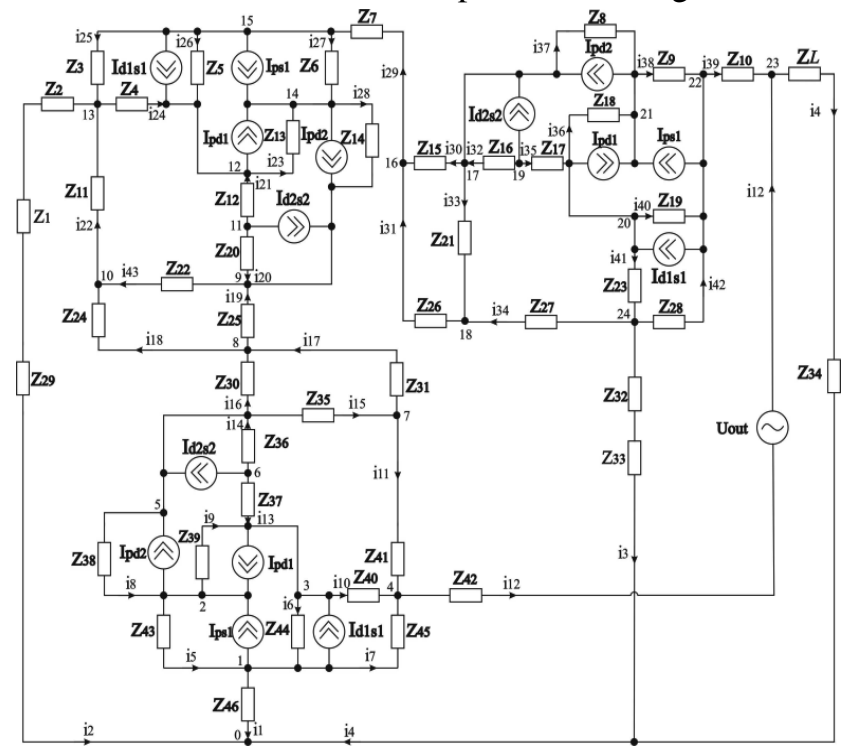

Fig. 3. Transformed equivalent AC circuit of optical transducer with an active inductive element 
The Kirchhoff's system of equations for AC has been obtained for the equivalent circuit shown in Fig. 3 (1):

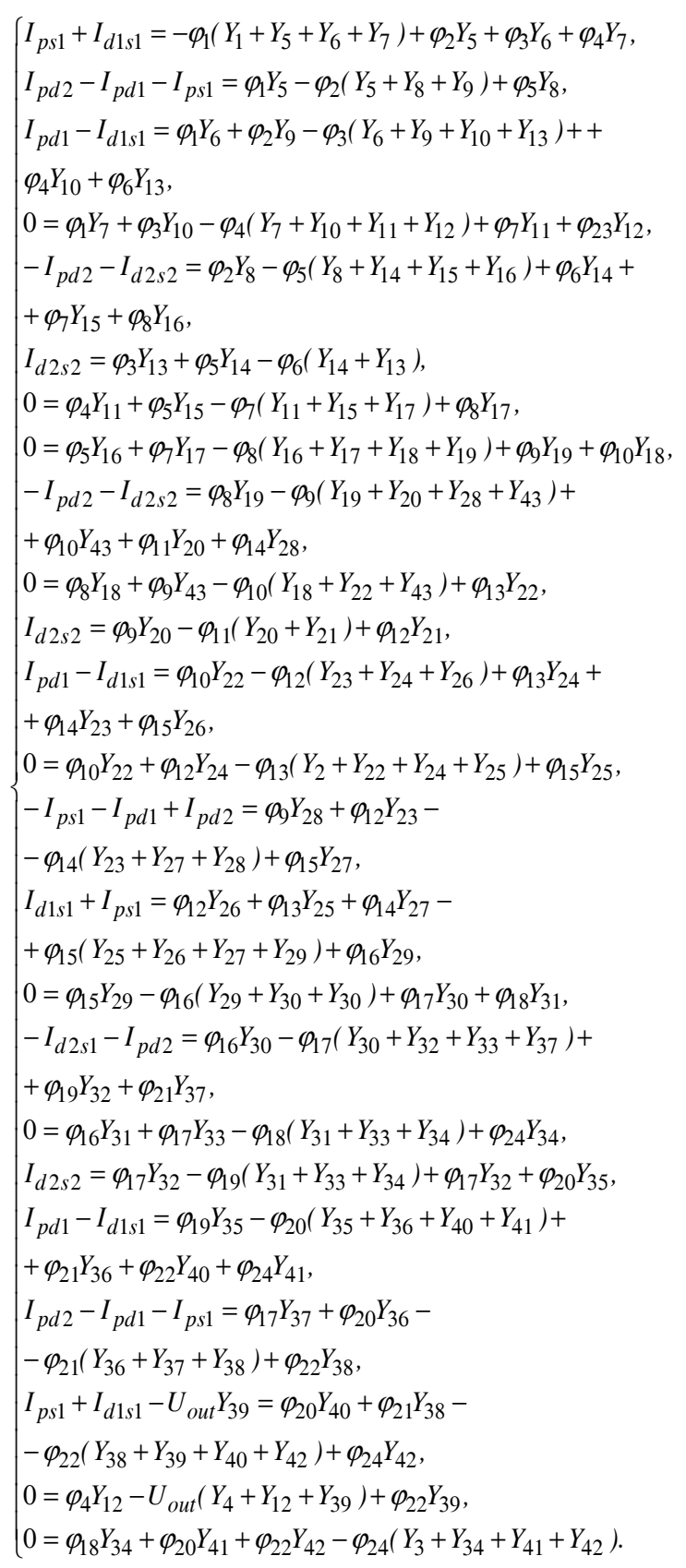

The conductivity of the circuit branches are defined as:

$Y_{1}=1 / Z_{46} ; \quad Y_{2}=1 /\left(Z_{1}+Z_{2}+Z_{29}\right) ; \quad Y_{3}=1 /\left(Z_{32}+Z_{33}\right) ;$ $Y_{4}=1 /\left(Z_{L}+Z_{34}\right) ; \quad Y_{5}=Z_{43} ; \quad Y_{6}=1 / Z_{44} ; \quad Y_{7}=Z_{45} ;$ $Y_{8}=1 / Z_{38} ; \quad Y_{9}=1 / Z_{39} ; \quad Y_{10}=1 / Z_{40} ; \quad Y_{11}=1 / Z_{41} ;$ $Y_{12}=1 / Z_{42} ; \quad Y_{13}=1 / Z_{37} ; \quad Y_{14}=Z_{36} ; \quad Y_{15}=1 / Z_{35} ;$ $Y_{16}=1 / Z_{30} ; \quad Y_{17}=1 / Z_{31} ; \quad Y_{18}=Z_{24} ; \quad Y_{19}=1 / Z_{25} ;$ $Y_{20}=1 / Z_{20} ; \quad Y_{21}=1 / Z_{12} ; \quad Y_{22}=1 / Z_{11} ; Y_{23}=1 / Z_{13} ;$ $Y_{24}=1 / Z_{4} ; \quad Y_{25}=1 / Z_{3} ; \quad Y_{26}=1 / Z_{5} ; \quad Y_{27}=1 / Z_{6} ;$
$Y_{28}=1 / Z_{14} ; \quad Y_{29}=1 / Z_{7} ; \quad Y_{30}=1 / Z_{15} ; \quad Y_{31}=1 / Z_{26} ;$ $Y_{32}=1 / Z_{16} ; \quad Y_{33}=1 / Z_{21} ; \quad Y_{34}=1 / Z_{27} ; \quad Y_{35}=1 / Z_{17} ;$ $Y_{36}=1 / Z_{18} ; \quad Y_{37}=1 / Z_{8} ; \quad Y_{38}=1 / Z_{9} ; \quad Y_{39}=1 / Z_{8} ;$ $Y_{40}=1 / Z_{19} ; Y_{41}=1 / Z_{23} ; Y_{42}=1 / Z_{28} ; Y_{43}=1 / Z_{22}$.

In order to calculate the impedance it is necessary to solve the Kirchhoff's system of equations for AC, obtained for the equivalent circuit shown in Fig. 3, using circuit node 0 as a basic.

The symbols used in the equivalent circuit (Fig. 3) are defined as:

$$
\begin{aligned}
& Z_{1}=\frac{R_{f}}{1+\omega^{2} R_{f}^{2} C_{f}^{2}}-j \frac{R_{f}^{2} \omega C_{f}}{1+\omega^{2} R_{f}^{2} C_{f}^{2}} ; Z_{2}=R_{g 1}^{I I} ; \\
& Z_{3}=R_{g 1 s 1}^{I I} /\left(1+\omega^{2}\left(R_{g 1 s 1}^{I I}\right)^{2}\left(C_{g 1 s 1}^{I I}\right)^{2}\right)- \\
& -j\left(\left(R_{g 1 s 1}^{I I}\right)^{2} \omega C_{g 1 s 1}^{I I} /\left(1+\omega^{2}\left(R_{g 1 s 1}^{I I}\right)^{2}\left(C_{g 1 s 1}^{I I}\right)^{2}\right)\right) ; \\
& Z_{4}=-j /\left(\omega C_{g 1 d 1}^{I I}\right) ; Z_{5}=R_{d 1 s 1}^{I I} ; \\
& Z_{6}=R_{p}^{I I} /\left(1+\omega^{2}\left(R_{p}^{I I}\right)^{2}\left(C_{p s 1}^{I I}\right)^{2}\right)- \\
& -j\left(\left(R_{p}^{I I}\right)^{2} \omega C_{p s 1}^{I I} /\left(1+\omega^{2}\left(R_{p}^{I I}\right)^{2}\left(C_{p s 1}^{I I}\right)^{2}\right)\right) ; \\
& Z_{7}=R_{s 1}^{I I} ; Z_{8}=-j /\left(\omega C_{p d 2}^{I}\right) ; \\
& Z_{9}=R_{p}^{I} /\left(1+\omega^{2}\left(R_{p}^{I}\right)^{2}\left(C_{p s 1}^{I}\right)^{2}\right)- \\
& -j\left(\left(R_{p}^{I}\right)^{2} \omega C_{p s 1}^{I} /\left(1+\omega^{2}\left(R_{p}^{I}\right)^{2}\left(C_{p s 1}^{I}\right)^{2}\right)\right) ; \\
& Z_{10}=R_{s 1}^{I} ; Z_{11}=-j / \omega\left(C_{g 1 g 2}^{I I}\right) ; Z_{12}=R_{d 1 s 2}^{I I} ; \\
& Z_{13}=-j /\left(\omega C_{p d 1}^{I I}\right) ; Z_{14}=-j /\left(\omega C_{p d 2}^{I I}\right) ; Z_{15}=R_{d 2}^{I} ; \\
& Z_{16}=R_{d 2 s 2}^{I} ; Z_{17}=R_{d 1 s 2}^{I} ; Z_{18}=-j /\left(\omega C_{p d 1}^{I}\right) ; Z_{19}=R_{d 1 s 1}^{I} ; \\
& Z_{20}=R_{d 2 s 2}^{I I} ; \\
& Z_{21}=R_{g 2 s 2}^{I} /\left(1+\omega^{2}\left(R_{g 2 s 2}^{I}\right)^{2}\left(C_{g 2 s 2}^{I}\right)^{2}\right)- \\
& -j\left(\left(R_{g 2 s 2}^{I}\right)^{2} \omega C_{g 2 s 2}^{I} /\left(1+\omega^{2}\left(R_{g 2 s 2}^{I}\right)^{2}\left(C_{g 2 s 2}^{I}\right)^{2}\right)\right) ; \\
& Z_{22}=R_{g 2 s 2}^{I I} /\left(1+\omega^{2}\left(R_{g 2 s 2}^{I I}\right)^{2}\left(C_{g 2 s 2}^{I I}\right)^{2}\right)- \\
& -j\left(\left(R_{g 2 s 2}^{I I}\right)^{2} \omega C_{g 2 s 2}^{I I} /\left(1+\omega^{2}\left(R_{g 2 s 2}^{I I}\right)^{2}\left(C_{g 2 s 2}^{I I}\right)^{2}\right)\right) ; \\
& Z_{23}=-j /\left(\omega C_{g 1 d 1}^{I}\right) ; Z_{24}=R_{g 2}^{I I} ; Z_{25}=R_{d 2}^{I I} ; Z_{26}=R_{g 2}^{I} ;
\end{aligned}
$$$$
Z_{28}=R_{g 1 s 1}^{I} /\left(1+\omega^{2}\left(R_{g 1 s 1}^{I}\right)^{2}\left(C_{g 1 s 1}^{I}\right)^{2}\right)-
$$$$
-j\left(\left(R_{g 1 s 1}^{I}\right)^{2} \omega C_{g 1 s 1}^{I} /\left(1+\omega^{2}\left(R_{g 1 s 1}^{I}\right)^{2}\left(C_{g 1 s 1}^{I}\right)^{2}\right)\right) \text {; }
$$$$
Z_{27}=-j /\left(\omega C_{p d 2}^{I}\right) ; Z_{29}=-j /\left(\omega C_{1}\right) ; Z_{30}=R_{d 2}^{I I I} ;
$$$$
Z_{31}=R_{g 2}^{I I I} \quad Z_{32}=R_{g 1}^{I} \text {; }
$$$$
Z_{33}=R_{2} ; Z_{34}=-j /\left(\omega C_{2}\right) ; Z_{36}=R_{d 2 s 2}^{I I I} ;
$$$$
Z_{35}=R_{g 2 s 2}^{I I I} /\left(1+\omega^{2}\left(R_{g 2 s 2}^{I I I}\right)^{2}\left(C_{g 2 s 2}^{I I I}\right)^{2}\right)-
$$$$
-j\left(\left(R_{g 2 s 2}^{I I I}\right)^{2} \omega C_{g 2 s 2}^{I I I} /\left(1+\omega^{2}\left(R_{g 2 s 2}^{I I I}\right)^{2}\left(C_{g 2 s 2}^{I I I}\right)^{2}\right)\right) ;
$$ 
$Z_{37}=R_{d 1 s 2}^{I I I} ; Z_{38}=-j /\left(\omega C_{p d 2}^{I I I}\right) ; Z_{39}=-j /\left(\omega C_{p d 1}^{I I I}\right) ;$

$Z_{40}=-j /\left(\omega C_{g 1 d 1}^{I I I}\right) ; Z_{41}=-j / \omega\left(C_{g 1 g 2}^{I I I}\right) ;$

$Z_{43}=R_{p}^{I I I} /\left(1+\omega^{2}\left(R_{p}^{I I I}\right)^{2}\left(C_{p s 1}^{I I I}\right)^{2}\right)-$

$-j\left(\left(R_{p}^{I I I}\right)^{2} \omega C_{p s 1}^{I I I} /\left(1+\omega^{2}\left(R_{p}^{I I I}\right)^{2}\left(C_{p s 1}^{I I I}\right)^{2}\right)\right)$;

$Z_{42}=R_{g 1}^{I I I} ; Z_{44}=R_{d 1 s 1}^{I I I} ; Z_{46}=R_{s 1}^{I I I} ;$

$Z_{45}=R_{g 1 s 1}^{I I I} /\left(1+\omega^{2}\left(R_{g 1 s 1}^{I I I}\right)^{2}\left(C_{g 1 s 1}^{I I I}\right)^{2}\right)-$

$-j\left(\left(R_{g 1 s 1}^{I I I}\right)^{2} \omega C_{g 1 s 1}^{I I I} /\left(1+\omega^{2}\left(R_{g 1 s 1}^{I I I}\right)^{2}\left(C_{g 1 s 1}^{I I I}\right)^{2}\right)\right)$,

where

$R_{1}$ and $R_{2}$ - the resistances of resistors $R_{1}$ and $R_{2}$ respectively, $R_{f}$ - the photoresistor resistance $R_{f}, R_{g 1}^{I}$, $R_{g 1}^{I I}, R_{g 1}^{I I I}$ - the bulk resistances of gates of VT1, VT2 and VT3 transistors respectively; $R_{g 1 s 1}^{I}, R_{g 1 s 1}^{I I}, R_{g 1 s 1}^{I I I}$ та $R_{g 2 s 2}^{I}, R_{g 2 s 2}^{I I}, R_{g 2 s 2}^{I I I}$ - the bulk resistances of gate-source MOS transistors VT1, VT2 and VT3; $R_{d 1 s 1}^{I}, R_{d 1 s 1}^{I I}$, $R_{d 1 s 1}^{I I I}, R_{d 1 s 2}^{I}, R_{d 1 s 2}^{I I}, R_{d 1 s 2}^{I I I}, R_{d 2 s 2}^{I}, R_{d 2 s 2}^{I I}, R_{d 2 s 2}^{I I I}$ - the resistances of drain-source MOS transistors VT1, VT2 and VT3; $R_{s 1}^{I}, R_{s 1}^{I I}, R_{s 1}^{I I I}$ - the bulk resistances of source of MOS transistors VT1, VT2 and VT3; $R_{d 2}^{I}, R_{d 2}^{I I}, R_{d 2}^{I I I}$ - the bulk resistances of drain of MOS transistors VT1, VT2 and VT3; $R_{g 1}^{I}, R_{g 1}^{I I}, R_{g 1}^{I I I}, R_{g 2}^{I}, R_{g 2}^{I I}, R_{g 2}^{I I I}$ - the bulk resistances of first and second gates of MOS transistors VT1, VT2 та VT3; $R_{p}^{I}, R_{p}^{I I}, R_{p}^{I I I}$ - the resistances of bodies of MOS transistors VT1, VT2 and VT3; $C_{f}$ - the capacity of photoresistor $R_{f} ; R_{e}, R_{c}, R_{b}$ - the resistances of emiter, collector and base of transistor VT4 respectively; $C_{b x}$ - the capacity between base terminal and collector terminal of bipolar transistor VT4; $C_{c}, C_{e}$ - the capasities of a base-collector junction and a base-emitter junction of bipolar transistor VT4 respectively; $C_{g 1 s 1}^{I}, C_{g 1 s 1}^{I I}, C_{g 1 s 1}^{I I I}, C_{g 2 s 2}^{I}, C_{g 2 s 2}^{I I}$, $C_{g 2 s 2}^{I I I} \square$ the capacities of gate-source of MOS transistors VT1, VT2 and VT3; $C_{g 1 d 1}^{I}, C_{g 1 d 1}^{I I}, C_{g 1 d 1}^{I I I}$ - the capacities of gate-drain of MOS transistors VT1, VT2 and VT3; $C_{p s 1}^{I I}, C_{p s 1}^{I I}, C_{p s 1}^{I I}$ - the capacities of body-source of MOS transistors VT1, VT2 and VT3; $C_{p d 1}^{I}, C_{p d 1}^{I I}, C_{p d 1}^{I I I}$, $C_{p d 2}^{I}, C_{p d 2}^{I I}, C_{p d 2}^{I I I}$ - the capacities body-drain of MOS transistors VT1, VT2 and VT3; $C_{g 1 g 2}^{I}, C_{g 1 g 2}^{I I}, C_{g 1 g 2}^{I I I}$ the capacities between first and second gates MOS transistors VT1, VT2 and VT3; $C_{1} C_{2}$ and $C_{3}$ - the capacities of capacitors $C_{1}, C_{2}$ and $C_{3}$ respectively.

The circuit in Fig. 4 was used to determine the impedance of active inductive element $Z_{L}$ :

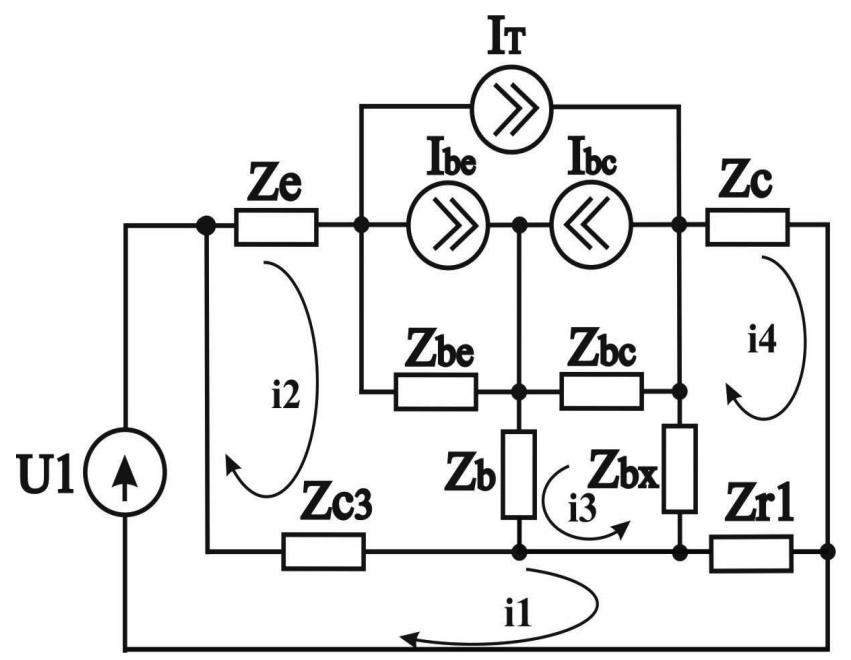

Fig. 4. Transformed equivalent AC circuit of the active inductive element

The Kirchhoff's system of equations for AC was built to determine impedance of active inductive element:

$$
\left\{\begin{array}{l}
U_{1}=i_{1} A_{1}-i_{2} Z_{c 3}-i_{4} Z_{r 1} ; \\
0=-i_{1} Z_{c 3}+i_{2} A_{2}+i_{3} Z_{b}+A_{3} \\
0=i_{2} Z_{b}+i_{3} A_{4}+i_{4} Z_{b x}+A_{5} ; \\
0=-i_{1} Z_{r 1}+i_{3} Z_{b x}+i_{4} A_{6},
\end{array}\right.
$$

where

$A_{1}=Z_{c 3}+Z_{r 1}$,

$A_{2}=Z_{e}+Z_{b e}+Z_{c 3}+Z_{b}$,

$A_{3}=Z_{b e}\left(I_{b c}-I_{b e}-I_{T}\right)$,

$A_{4}=Z_{b c}+Z_{b x}+Z_{b}$,

$A_{5}=Z_{b c}\left(I_{b e}-I_{b c}+I_{T}\right)$;

$A_{6}=Z_{b x}+Z_{c}+Z_{r 1}$.

Solving the system of equations (2) gives the current relative impedance transistor equivalent inductance $Z_{L}$ :

$Z_{L}=U_{1} /\left(\frac{U_{1}}{K_{1}}+\frac{A_{5} A_{6} Z_{c 3} Z_{b}}{B_{1} K_{1} Z_{b x}\left(Z_{b x}-A_{4} A_{6} / Z_{b x}\right)}-\frac{Z_{c 3} A_{3}}{K_{1} B_{1}}+\right.$

$+\frac{Z_{r 1} A_{5}}{K_{1}\left(Z_{b x}-A_{4} A_{6} / Z_{b x}\right)}-\frac{A_{5} A_{6} B_{2} Z_{b}}{B_{1} K_{1} Z_{b x}\left(Z_{b x}-A_{4} A_{6} / Z_{b x}\right)}+\frac{A_{3} B_{2}}{B_{1} K_{1}}$, 
where

$$
\begin{aligned}
& B_{1}=A_{2}+Z_{b}^{2} A_{6} /\left(Z_{b x}\left(Z_{b x}-A_{4} A_{6} / Z_{b x}\right)\right), \\
& B_{2}=Z_{b} Z_{r 1} /\left(Z_{b x}-A_{4} A_{6} / Z_{b x}\right) ; \\
& K_{1}=A_{1}-Z_{c 3}^{2} / B_{1}+Z_{c 3} Z_{b} Z_{r 1} /\left(B_{1} Z_{b x}\right)+ \\
& +Z_{c 3} Z_{b} Z_{r 1} A_{4} A_{6} /\left(B_{1} Z_{b x}^{2}\left(Z_{b x}-A_{4} A_{6} / Z_{b x}\right)\right)+ \\
& +Z_{r 1}^{2} A_{4} /\left(Z_{b x}\left(Z_{b x}-A_{4} A_{6} / Z_{b x}\right)\right)+Z_{c 3} B_{2} / B_{1}- \\
& -Z_{b} Z_{r 1} B_{2} /\left(Z_{b x} B_{1}\right) .
\end{aligned}
$$

The system of equations (1) was solved using Gauss's method in the software package MATLAB 8.1.

Calculated and experimental dependencies of active and reactive component of the impedance on the optical power are shown on Fig. 5 and Fig. 6, respectively.

The reactive component of the impedance has a maximum value for supply voltage $4 \mathrm{~V}$ and decreases with decreasing power of optical radiation.

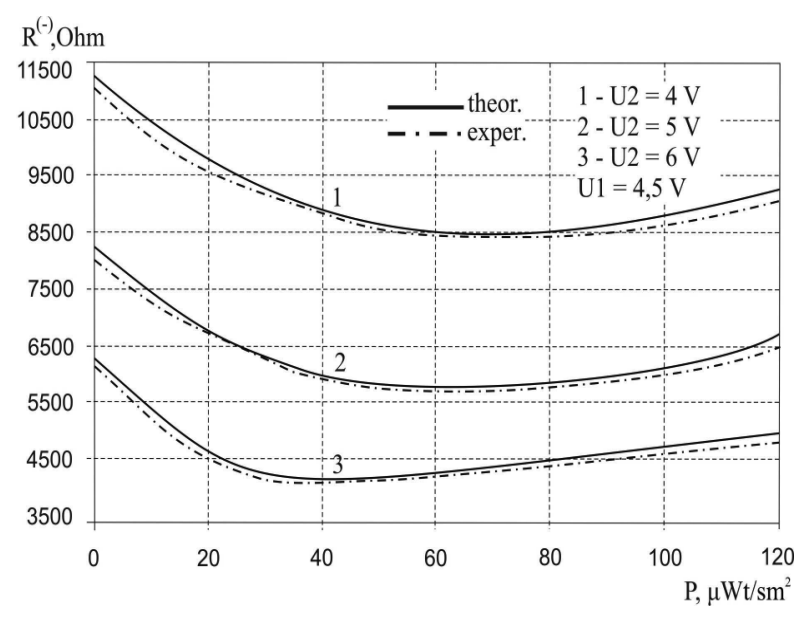

Fig. 5. Theoretical and experimental dependenices of active component of the impedance on power of optical radiation

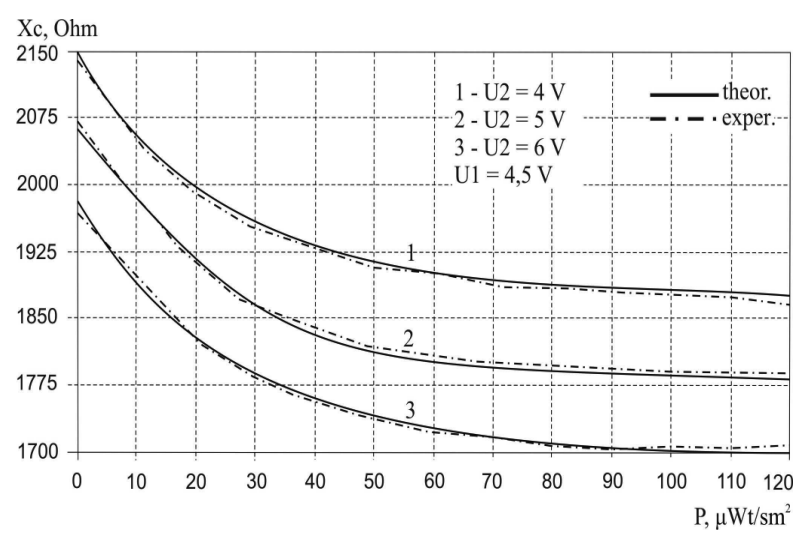

Fig. 6. Theoretical and experimental dependencies of reactive component of the impedance on power of optical radiation

In order to determine the transfer functions, it is necessary to obtain the dependence of oscillation frequency on power of optical radiation by means of the circuit reverse current in accordance Fig. 3 based on Lyapunov stability theory [12]. The estimated transfer function is expressed as

$$
F=\frac{\sqrt{2} \sqrt{L_{e k v} C_{4}\left(-L_{e k v} C_{p d 2}^{\prime}+R_{f}^{2}(P) C_{f}^{2}+R_{f}^{2}(P) C_{f} C_{p d 2}^{\prime}+A_{1}\right)}}{2 L_{e k v} C_{f} C_{p d 2}^{\prime} R_{f}(P)}
$$

where

$$
\begin{aligned}
& A_{1}=\sqrt{\begin{array}{l}
L_{e k v}^{2}\left(C_{p d 2}^{\prime}\right)^{2}+2 L_{e k v} C_{f}^{2} C_{p d 2}^{\prime} R_{f}^{2}(P)- \\
-2 L_{e k v}\left(C_{p d 2}^{\prime}\right)^{2} C_{f} R_{f}^{2}(P)+A_{2},
\end{array}} \\
& A_{2}=R_{f}^{4}(P) C_{f}^{4}+2 R_{f}^{4}(P) C_{f}^{3} C_{p d 2}^{\prime}+R_{f}^{4}(P) C_{f}^{2}\left(C_{p d 2}^{\prime}\right)^{2} .
\end{aligned}
$$

The sensitivity of the frequency transducer has been calculated using equation (3)

$$
\begin{aligned}
& S_{P}^{F}=\frac{1}{4} \sqrt{2}\left(2 R_{f}(P) C_{f}^{2}\left(\frac{\partial}{\partial P} R_{f}(P)\right)+\right. \\
& 2 R_{f}(P) C_{f} C_{p d 2}^{\prime}\left(\frac{\partial}{\partial P} R_{f}(P)\right)+ \\
& +\left(\frac { 1 } { 2 } \left(4 L_{e k v} R_{f}(P) C_{p d 2}^{\prime} C_{f}^{2}\left(\frac{\partial}{\partial P} R_{f}(P)\right)-\right.\right. \\
& -4 L_{e k v} R_{f}(P)\left(C_{p d 2}^{\prime}\right)^{2} C_{f}\left(\frac{\partial}{\partial P} R_{f}(P)\right)+ \\
& +4 R_{f}^{3}(P) C_{f}^{4}\left(\frac{\partial}{\partial P} R_{f}(P)\right)+8 R_{f}^{3}(P) C_{f}^{3} C_{p d 2}^{\prime}\left(\frac{\partial}{\partial P} R_{f}(P)\right)+ \\
& \left.\left.+4 R_{f}^{3}(P) C_{f}^{2}\left(C_{p d 2}^{\prime}\right)^{2}\left(\frac{\partial}{\partial P} R_{f}(P)\right)\right) / \sqrt{B_{1}}\right) / \\
& /\left(\sqrt{\left.-L_{e k v} C_{p d 2}^{\prime}\left(B_{2}+\sqrt{B_{1}}\right)\right)}\right)-\frac{1}{2} \sqrt{2} \times \\
& \times \sqrt{L_{e k v} C_{p d 2}^{\prime}\left(B_{2}+\sqrt{B_{1}}\right)}\left(\frac{\partial}{\partial P} R_{f}(P)\right) /\left(L_{e k v} C_{p d 2}^{\prime} C_{f} R_{f}^{2}(P)\right),
\end{aligned}
$$

where

$$
\begin{aligned}
& B_{1}=L_{e k v}^{2}\left(C_{p d 2}^{\prime}\right)^{2}+2 L_{e k v} C_{p d 2}^{\prime} C_{f}^{2} R_{f}^{2}(P)-2 L_{e k v}\left(C_{p d 2}^{\prime}\right)^{2} C_{f} R_{f}^{2}(P)+ \\
& +R_{f}^{4}(P) C f+2 R_{f}^{4}(P) C_{f}^{3} C_{p d 2}^{\prime}+R_{f}^{4}(P) C_{f}^{2}\left(C_{p d 2}^{\prime}\right)^{2} ; \\
& B_{2}=-L_{e k v} C_{p d 2}^{\prime}+R_{f}^{2}(P) C_{f}^{2}+R_{f}^{2}(P) C_{p d 2}^{\prime} C_{f} .
\end{aligned}
$$

Dependencies of oscillation frequency on power of optical radiation calculated by (3) and determined experimentally for transducer are shown in Fig. 7.

The plots (Fig. 7) show that at increase of optical radiation power from 0 up to $120 \mu \mathrm{Wt} / \mathrm{cm}^{2}$ the generation frequency decreases from $2440 \mathrm{kHz}$ up to $2080 \mathrm{kHz}$. 


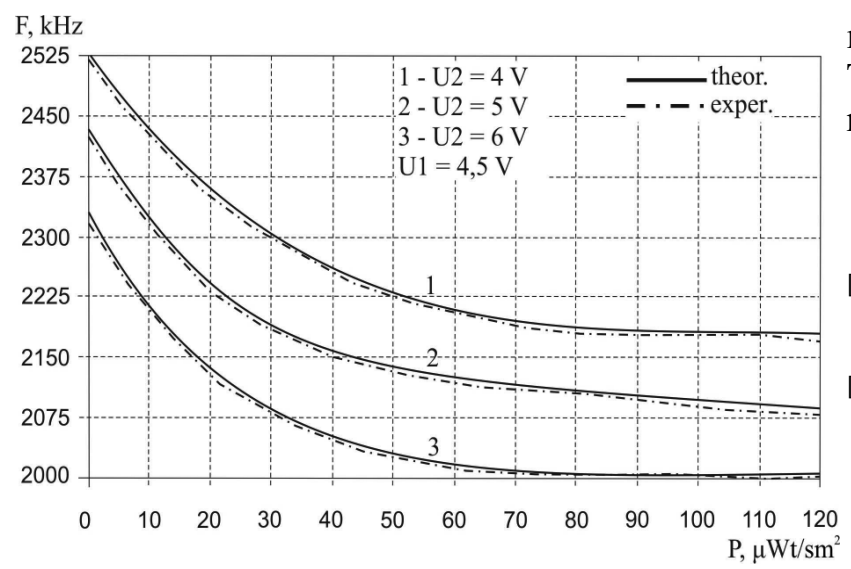

Fig. 7. Theoretical and experimental dependencies of the oscillation frequency on the power of optical radiation

The theoretical values are consistent with better than $\pm 5 \%$ with experimental data.

The dependence of the sensitivity of the optical frequency transducer on power of optical radiation is presented in Fig. 8.

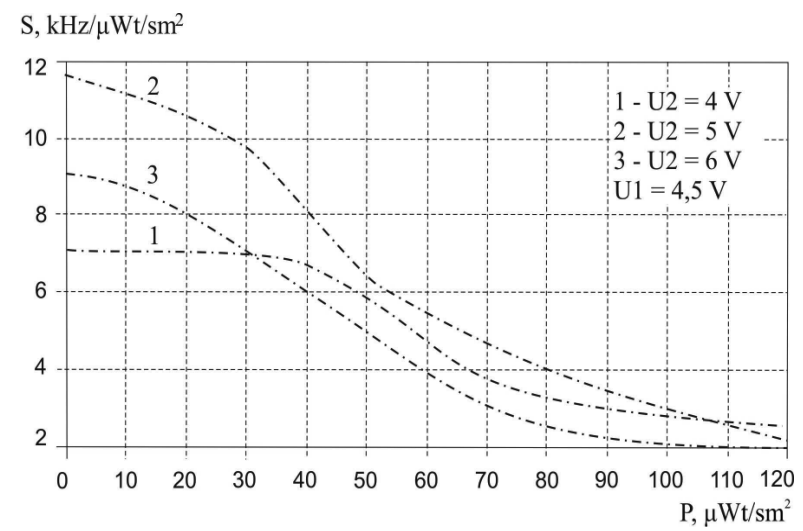

Fig. 8. The sensitivity of the optical frequency transducer based on dual-gate MOS field-effect transistors with an active inductive element

As it can be seen (Fig. 8), the greatest sensitivity of the device is within the range of power of optical radiation from 0 up to $50 \mu \mathrm{Wt} / \mathrm{cm}^{2}$ and makes 6.2-11.6 $\mathrm{kHz} / \mu \mathrm{Wt} / \mathrm{cm}^{2}$. The greatest sensitivity matches the optimum mode of supply $5 \mathrm{~V}$.

\section{Conclutions}

The mathematical model of optical frequency transducer with an active inductive element, based on oscillator with MOS transistors, with photoresistor as the sensing element was developed. The analytic expressions for the transfer function and sensitivity equation have been obtained using the mathematical model. Proposed model describes the dependence of the impedance of the transistor structure, - which is basic for the transducer on power of optical radiation. The transducer has a high sensitivity in the range of low values of optical power. It makes possible to measure even low optical signals. Theoretical and experimental dependencies show that relative sensitivity is equal to $2-11.5 \mathrm{kHz} / \mu \mathrm{Wt} / \mathrm{cm}^{2}$.

\section{References}

11] E. Krioukov, D. J. W. Klunder, A. Driessen, J. Greve, and C. Otto. "Sensor based on an integrated optical microcavity", Optics Letters. vol. 27, issue 7, 2002, pp. 512-514.

[2] Karri L. Michael, Laura C. Taylor, Sandra L. Schultz and David R. "Walt Randomly Ordered Addressable High-Density Optical Sensor Arrays", Max Tishler Laboratory for Organic Chemistry, Department of Chemistry, Tufts University, Medford, Massachusetts 02155. Anal. Chem., vol. 70 (7), 1998, pp. 12421248.

[3] Microelectronic sensors of physical quantities. Edited Z.Yu..Hotra. In 3 volumes. - Lvov: League-Press, 2003. Vol.2.

[4] Kwang-Jow Gan, Dong-Shong Liang, Chung-Chih Hsiao, CherShiung Tsai and Yaw-Hwang Chen. Investigation of MOS-NDR Voltage Controlled Ring Oscillator Fabricated by CMOS Process. 2005 IEEE Conference on Electron Devices and SolidState Circuits, 2005. pp. 825-827. DOI: 10.1109/EDSSC.2005.1635405

[5] Kwang-Jow Gan, Kuan-Yu Chun, Wen-Kuan Yeh. Design of Dynamic Frequency Divider using Negative Differential Resistance Circuit. International Journal on Recent and Innovation Trends in Computing and Communication. 2015. Volume: 3 Issue: 8. pp.5224-5228.

[6] P.V. Novitsky, V.G. Knoring, V.S. Gutnikov. Digital devices with frequency sensors. -Leningrad: Energy, 1970.

[7] V. S. Osadchuk, O. V. Osadchuk and O. O. Seletska, Radiomeasuring optical converters for microelectronic technology, Monograph: Universum, Vinnytsia, Ukraine, 2013.

[8] J. Núñez, M. J. Avedillo and J. M. Quintana. Bifurcation diagrams in MOS-NDR frequency divider circuits. 2012 19th IEEE International Conference on Electronics, Circuits, and Systems (ICECS 2012), Seville, 2012. pp. 480-483. DOI: 10.1109/ICECS.2012. 6463558

[9] A. V. Osadchuk, Microelectronic frequency transducers based on transistor structures with negative resistance, Universum, Vinnytsia, Ukraine, 2000.

[10] D. S. Liang, K. J. Gan and K. Y. Chun. Frequency divider design using the A-type negative-differential-resistance circuit. 2010 53rd IEEE International Midwest Symposium on Circuits and Systems, Seattle, WA, 2010. pp. 969-972. DOI: 10.1109/MWSCAS.2010.5548795

[11] V. S. Osadchuk, A.V. Osadchuk, "Radiomeasuring Microelectronic Transducers of Physical Quantities", IEEE, Proceedings of the International Siberian Conference on Control and Communications (SIBCON), 21-23 May 2015.

[12] Kayatskas A.A. Basics of electronics. Moskow: Executive. wk., 1988. 


\section{Осадчук О.В., Осадчук В.С., Селецька О.О., Крилик Л.В.}

\section{Оптичний частотний перетворювач на основі двозатворних МОН-транзисторів з активним індуктивним елементом}

Проблематика. Перспективним напрямком розвитку перетворювачів оптичного випромінювання $\epsilon$ використання залежності реактивних властивостей напівпровідникових транзисторних структур з від'ємним опором від впливу оптичного випромінювання та створення частотих перетворювачів оптичного випромінювання на основі цих властивостей. Використання оптико-частотного принципу перетворення підвищує завадостійкість, точність, дає змогу отримати значно більші вихідні сигнали ніж дають амплітудні перетворювачі та покращити метрологічні показники перетворювачів. Використання частоти як інформативного параметру виключає використання аналогоцифрових перетворювачів під час обробки інформації, що понижує собівартість систем контролю та управління. Перетворення «потужність оптичного випромінювання частота» можливо реалізувати за допомогою напівпровідникової структури, що містить автогенераторний пристрій, реалізованого у вигляді схеми, що складається 3 двозатворних МДП-транзисторів і фоторезистора в якості фоточутливого елемента. Використання активної індуктивності в такій структурі вирішує проблему низької добротності пасивної індуктивності та несумісності їі розмірів з розмірами інтегральних мікросхем i, відповідно, дає можливість реалізувати оптичний перетворювач у інтегральному виконанні. Для вивчення властивостей частотного оптичного перетворювача необхідно розробити математичну модель, за допомогою якої отримують залежності, активної та реактивної складових повного опору структури, чутливості та частоти генерації від потужності оптичного випромінювання.

Мета досліджень. Метою роботи є визначення функції перетворення та рівняння чутливості перетворювача шляхом розв'язку системи рівнянь рівнянь Кірхгофа, складеної на основі його еквівалентної схеми.

Методика реалізації. Визначення повного опору транзисторної структури проводилося шляхом розв'язування системи рівнянь Кірхгофа, складеної для еквівалентної схеми частотного оптичного перетворювача. Характеристики, що описують залежності реактивної та активної складової повного опору автогенераторного перетворювача від оптичної потужності, були отримані шляхом комп'ютерного моделювання за допомогою математичного пакету MATLAB 8.1.

Результати досліджень. Розроблена математична модель необхідна для опису властивостей оптичного частотного перетворювача 3 активним індуктивним елементом. На основі моделі отримано аналітичні вирази для функції перетворення та рівняння чутливості. Теоретичні та експериментальні залежності показали, що чутливість розробленого оптичного перетворювача 2 - 11,5 кГц/мкВт/см2. Похибка розробленої математичної моделі становить $\pm 5 \%$.

Висновки. Оптичний перетворювач з активним індуктивним елементом має високу чутливість у діапазоні низьких значень оптичної потужності. Це дає можливість вимірювати навіть слабкі оптичні сигнали. Запропонована модель описує залежність повного опору транзисторної структури, яка лежить в основі перетворювача, від впливу потужності оптичного випромінювання.

Ключові слова: оптичні перетворювачі; частотні перетворювачі; від’ємний опір; фоторезистор.

\section{Осадчук А.В., Осадчук В.С., Селецкая Е.А., Крылык Л.В.}

\section{Оптический частотный преобразователь на основе двухзатворных МОН-транзисторов с}

\section{активным индуктивным элементом}

Проблематика. Перспективным направлением развития преобразователей оптического излучения является использование зависимости реактивных свойств полупроводниковых транзисторных структур с отрицательным сопротивлением от воздействия оптического излучения и создание частотных преобразователей оптического излучения на основе этих свойств. Использование оптико-частотного принципа преобразования повышает помехоустойчивость, точность, позволяет получить значительно большие выходные сигналы в сравнении с амплитудными преобразователями и улучшить метрологические показатели преобразователей. Использование частоты как информативного параметра исключает использования аналого-цифровых преобразователей во время обработки информации, снижает себестоимость систем контроля и управления. Преобразование «мощность оптического излучения частота» возможно реализовать с помощью полупроводниковой структуры, содержащей автогенераторное устройство реализованное в виде схемы, состоящей из двухзатворных МДП-транзисторов и фоторезистора в качестве фоточувствительного элемента. Использование активной индуктивности в такой структуре решает проблему низкой добротности пассивной индуктивности и несовместимости ее размеров с размерами интегральных микросхем и, соответственно, дает возможность реализовать оптический преобразователь в интегральном исполнении. Для изучения свойств частотного оптического преобразователя необходимо разработать математическую модель, с помощью которой получают зависимости, активной и реактивной составляющих полного сопротивления структуры, чувствительности и частоты генерации от мощности оптического излучения. 
Цель исследований. Целью работы является определение функции преобразования и уравнения чувствительности преобразователя решением системы уравнений Кирхгофа, составленной на основе его эквивалентной схемы.

Методика реализации. Определение полного сопротивления транзисторной структуры проводилось путем решения системы уравнений Кирхгофа, составленной для эквивалентной схемы частотного оптического преобразователя. Характеристики, описывающие зависимости реактивной и активной составляющей полного сопротивления автогенераторного преобразователя от оптической мощности, были получены путем компьютерного моделирования с помощью математического пакета MATLAB 8.1.

Результаты исследований. Разработана математическая модель, необходимая для описания свойств оптического частотного преобразователя с активным индуктивным элементом. На основе модели получены аналитические выражения для преобразования и уравнение чувствительности. Теоретические и экспериментальные зависимости показали, что чувствительность разработанного оптического преобразователя равна 2-11,5 кГц/мкВт/см². Погрешность разработанной математической модели составляет $\pm 5 \%$.

Выводы. Оптический преобразователь с активным индуктивным элементом имеет высокую чувствительность в диапазоне низких значений оптической мощности. Это дает возможность измерять даже слабые оптические сигналы. Предложенная модель описывает зависимость полного сопротивления транзисторной структуры, что лежит в основе преобразователя, от влияния мощности оптического излучения.

Ключевые слова: оптические преобразователи; частотные преобразователи; отрицательный сопротивление; фоторезистор. 